\title{
Social Distancing dan Tingkat Stress Pada Remaja Usia Sekolah di SMP Frater Mamasa
}

\author{
Mery Sambo ${ }^{1}$, Ni Wayan Riskyanti ${ }^{2}$, Neni Sombo Bamba ${ }^{3}$ \\ ${ }^{1,2,3}$ Program Studi Ilmu Keperawatan, Sekolah Tinggi Ilmu Kesehatan Stella Maris Makassar
}

\begin{tabular}{l}
\hline Info Artikel \\
\hline Riwayat Artikel: \\
Received : 16 Juni 2021 \\
Revised : 22 Juni 2021 \\
Accepted : 23 Juni 2021
\end{tabular}

Kata Kunci:

Social Distancing

Tingkat Stres

Remaja

\begin{abstract}
ABSTRAK
Covid 19 telah mengubah konstruksi hubungan dan pola komunikasi manusia, hal ini juga terjadi pada kelompok usia Remaja. Remaja dengan berbagai masalah psikologis seperti masalah storm dan stress. Salah satu ciri perkembangan remaja adalah konsisten dan setia dengan lingkungan sosialnya. Pandemi covid 19 memaksa pemerintah membuat beberapa aturan untuk mencegah penyebaran virus, salah satunya adalah social distancing. Aturan social distancing membuat remaja tidak bisa melakukan aktivitas seharihari mereka seperti biasanya sehingga dapat menimbulkan stress. Penelitian ini bertujuan untuk mengetahui hubungan antara social distancing dengan tingkat stres pada remaja usia sekolah. Jenis penelitian ini adalah observasional analitik dengan desain cross sectional study. Pengambilan sampel menggunakan propotional stratified sampling dengan jumlah 76 responden. Instrumen yang digunakan untuk mengukur persepsi social distancing adalah Short Social Participation Questionnaire-Lockdowns (SSPQ-L), untuk mengukur tingkat stress menggunakan kuesioner DASS-42. Uji statistic menggunakan uji chi-square dan diperoleh $\mathrm{p}=0.000$ $(\alpha=0.05)$, yang berarti social distancing memiliki hubungan dengan tingkat stres pada remaja usia sekolah SMP Frater Mamasa. Anak remaja dengan social distancing dapat mempengaruhi tingkat stresnya.
\end{abstract}

\section{Corresponding Author:}

Mery Sambo,

Prodi Ilmu Keperawatan, STIK Stella Maris,

Jl. Maipa No. 19, Makassar, Indonesia.

Email: sambomery@gmail.com

\section{PENDAHULUAN}

World Health Organization (WHO) mengumumkan kasus pneumonia yang terjadi di Wuhan Tiongkok pada bulan Desember 2019 yang disebabkan oleh virus corona terbaru yang disebut covid-19. Penyebaran virus covid 19 merupakan fenomena sosial yang melekat, dan keberhasilan penahanan bergantung pada pembatasan kontaksosial secara efektif. Respon kesehatan masyarakat yang menekankan social distancing, termasuk perintah tinggal di rumah dan perubahan perilaku individu, tampaknya telah memperlambat lintasan Covid-19 saat diterapkan (Marroquín et al., 2020).

Namun selain dampak positif kebijakan ini juga menimbulkan dampak negatif khusus bagi mereka yang berusia muda atau remaja. Masa remaja usia sekolah adalah periode perkembangan biologis, psikologis, dan sosial yang berbeda karena tiga alasan utama. Pertama, perilaku khas remaja seperti pengambilan risiko yang tinggi dan pencarian sensasi dapat dilihat di berbagai budaya manusia yang berbeda. Kedua, ada bukti perilaku khas remaja di seluruh spesies, semua mamalia mengalami tahap perkembangan antara masa pubertas dan menjadi dewasa secara seksual, dan selama tahap tersebut terdapat bukti peningkatan pengambilan risiko, eksplorasi lingkungan, dan perubahan perilaku sosial. Ketiga, perilaku khas remaja didokumentasikan sepanjang sejarah. Selama masa remaja, waktu yang dihabiskan dengan teman biasanya meningkat, dibandingkan dengan masa kanak-kanak, dan evaluasi remaja terhadap nilai sosial dan pribadi 
mereka lebih bergantung pada pandangan teman sebayanya, hal ini menyebabkan remaja mudah mengalami stres karena keinginan yang kuat dalam menarik perhatian untuk eksistensi atau pengakuan dari temantemannya. Stres pada remaja juga terkait dengan hubungan belajar mengajar, terkait keinginan dan pengendalian, terkait aktivitas kelompok dan terkait hubungan social (Blakemore, 2019).

Pembatasan dalam beraktifitas, larangan untuk berkumpul bersama teman-teman, remaja yang cenderung lebih memilih kegiatan diluar sekarang hanya bisa dilakukan di dalam rumah, sehingga remaja mudah merasa bosan dan tertekan dengan situasi dan perubahan yang ada. Hal ini juga dirasakan bagi remaja awal yang masih duduk di bangku sekolah, beban tugas yang diberikan oleh guru, terlebih bagi mereka yang tinggal di deda-desa tertentu yang memiliki signal atau jaringan buruk, membuat pelajar semakin khawatir terhadap prestasi mereka. Ini beresiko terhadap dampak pada adanya tekanan mental salah satunya adalah stres. Menurut Piyeke et al., (2014) stres pada remaja yang terjadi secara berkepanjangan bisa melibatkan tanda seperti kecemasan dan ketidakmampuan untuk mengelolah emosi.

Negara Cina sendiri dilaporkan mengalami peningkatan stres pada tahap awal pandemik sebesar 8.1\% (Cullen et al., 2020). Sedangkan di Amerika Serikat juga mengalami peningkatan stres berat pada usia 18 ke atas yang sebelumnya $0.7 \%$ meningkat menjadi 5.1\% selama covid-19 (Ettman et al., 2020). Di India sebanyak 70\% mengalami stres dengan tingkat sedang (Kandeger et al., 2018). Di Indonesia sendiri menurut Mohammadi, (2020) dengan cara melakukan survey online yang berasal dari 34 Provinsi dengan responden sebagian adalah remaja usia sekolah menunjukan hasil sebanyak 64\% mengalami kecemasan dan 60\% mengalami depresi. Sedangkan di Kota Makassar menurut hasil survey dengan responden sebanyak 1917 $(50,89) \%$ perempuan dan $1850(49,11) \%$ laki-laki menunjukkan hasil mengalami peningkatan kecemasan tentang pemberitaan media sebanyak $67,74 \%$, kesehatan diri 54,07\%, saat keluar rumah 74,20\% (Badan Pusat Statistik, 2020). Hasil penelitian menunjukkan bahwa tingkat stres lebih banyak terjadi pada anak dan remaja, hal ini di karenakan adanya penutupan sekolah dan aturan yang membatasi ruang pertemuan remaja dengan teman sebayanya (Al Omari et al., 2020). Uraian di atas memperjelas bahwa anak remaja usia sekolah sangat sensitif secara mental terhadap perubahan keadaan selama pemberlakuan social distancing dengan penerapan PSBB.

Hasil wawancara dengan pihak sekolah yang dilakukan di SMP Frater Mamasa pada tanggal 18 Desember 2020 peneliti menemukan hasil bahwa kegiatan belajar mengajar selama pandemi dilakukan secara online (daring), pembatalan kegiatan drum band, kesenian dan olahraga.Menurut ketua osis pembatalan terhadap kegiatan sosial menyebabkan banyak kekecewaan dari teman-temannya karena telah melakukan persiapan sebelumnya. Ditambah adanya aturan social distancing yang menyebabkan mereka tidak bisa bertemu satu sama lain dengan teman-teman kelompoknya. Berdasarkan pernyataan-pernyataan di atas, dan karena belum pernah dilakukan penelitian hubungan social distancing dengan tingkat stres pada anak remaja usia sekolah di SMP Frater Mamasa, maka peneliti tertarik untuk melakukan penelitian hubungan social distancing dengan tingkat stres pada anak remaja usia sekolah di SMP Frater Mamasa. Tujuan penelitian ini untuk mengetahui hubungan antara social distancing dengan tingkat stres pada anak usia remaja di SMP Frater Mamasa.

\section{METODE PENELITIAN}

Penelitian ini menggunakan jenis penelitian observasional analitic dengan pendekatan cross sectional. Penelitian ini dilakukan di SMP Frater Mamasa dengan populasi berjumlah 362 orang. Pengambilan sampel menggunakan teknik propotional stratified random sampling dengan jumlah sampel 76 responden. Pengambilan sampel menggunakan probability sampling dengan pendekatan proportional stratified random. Instrumen yang digunakan untuk mengukur persepsi social distancing adalah Short Social Participation Questionnaire-Lockdowns (SSPQ-L) yang dimodifikasi sesuai dengan kebutuhan penelitian dan untuk mengukur tingkat stress menggunakan kuesioner DASS-42. Data yang terkumpul dianalisis menggunakan uji chi square dengan tingkat kemaknaan $5 \%(\alpha=0.05)$

\section{HASIL}

\subsection{Karakteristik Responden}

Tabel 1. Distribusi frekuensi responden berdasarkan jenis kelamin, usia, dan kelas

\begin{tabular}{ccc}
\cline { 2 - 3 } & Frequency & Percent \\
\hline Jenis kelamin & & 30.3 \\
Laki-laki & 23 & 69.7 \\
\hline Perempuan & 53 & 100,0 \\
\hline Total & 76 &
\end{tabular}


Jurnal Keperawatan Florence Nightingale, Vol. 4, No. 1, Juni 2021: pp. 41-45

\begin{tabular}{ccc}
12 tahun & 8 & 10.5 \\
13 tahun & 19 & 25.0 \\
14 tahun & 26 & 34.2 \\
15 tahun & 23 & 30.3 \\
\hline Total & 76 & 100,0 \\
\hline Kelas & & \\
VII & 25 & 32.9 \\
VIII & 26 & 34.2 \\
IX & 25 & 32.9 \\
\hline Total & 76 & 100.0 \\
\hline
\end{tabular}

Berdasarkan pada tabel. 1 diatas menunjukkan bahwa pada siswa di SMP Frater Mamasa yang berjumlah 76 responden dengan jenis kelamin terbanyak yaitu perempuan dengan jumlah 53 responden (69.7\%). Sedangkan untuk umur dengan jumlah terbanyak adalah umur 14 tahun yaitu berjumlah 26 (34.2\%) dan untuk kelas yang menjadi responden terbanyak adalah kelas VIII yaitu sebanyak 26 responden.

\subsection{Tabulasi silang dan analisis hubungan social distancing dengan tingkat stress}

Tabel 2. Tabulasi silang dan analisis hubungan social distancing dengan tingkat stres pada siswa-siswi SMP Frater Mamasa

\begin{tabular}{|c|c|c|c|c|c|c|c|c|c|c|c|}
\hline \multirow{3}{*}{$\begin{array}{c}\text { Social } \\
\text { Distancing }\end{array}$} & \multicolumn{11}{|c|}{ Stres } \\
\hline & \multicolumn{2}{|c|}{ Berat } & \multicolumn{2}{|c|}{ Sedang } & \multicolumn{2}{|c|}{ Ringan } & \multicolumn{2}{|c|}{$\begin{array}{l}\text { Tidak } \\
\text { Stres }\end{array}$} & \multicolumn{2}{|c|}{ Total } & \multirow{2}{*}{$\begin{array}{c}\text { Nilai } \\
p\end{array}$} \\
\hline & $\mathrm{n}$ & $\%$ & $\mathrm{n}$ & $\%$ & $\mathrm{n}$ & $\%$ & $n$ & $\%$ & $\mathrm{n}$ & $\%$ & \\
\hline Baik & 1 & 1.3 & 11 & 14,4 & 43 & 56,6 & 5 & 6,6 & 60 & 78,9 & \\
\hline Kurang & 0 & 0.0 & 0 & 0.0 & 0 & 0.0 & 16 & 21,9 & 16 & 21,9 & 0,000 \\
\hline Total & 1 & 1.3 & 11 & 14.5 & 43 & 56.6 & 21 & 27.6 & 76 & 100 & \\
\hline
\end{tabular}

Berdasarkan tabel. 2 dari 76 responden yang melakukan social distancing baik dengan tingkat stres berat yaitu 1 orang $(1,3 \%)$, tingkat sedang 11 orang (14.4\%), tingkat ringan 43 orang $(56,6 \%)$ dan tidak stres berjumlah 5 orang $(6,6 \%)$. Sedangkan responden yang tidak melakukan social distancing dan tidak mengalami stres sebanyak 16 responden (21.9\%). Hasil statistic dengan uji alternatif kolmogorov diperoleh nilai $\mathrm{p}=0.000$, hal ini menunjukan nilai $\mathrm{p}<\alpha$, artinya ada hubungan social distancing dengan tingkat stres pada remaja usia sekolah di SMP Frater Mamasa.

\section{DISKUSI}

Penelitian yang dilakukan di SMP Frater Mamasa diperoleh hasil terdapat hubungan antara social distancing dengan tingkat stres pada remaja dengan menggunakan uji alternatif Kolmogorov. Setiap remaja memiliki cara dan mekanisme masing-masing dalam menghadapi social distancing. Remaja sangat peka terhadap perubahan yang terjadi, dulu remaja sudah senang bermain di rumah bersama teman-teman, sekarang mereka terdorong untuk hangout di kafe dan menggunggah foto agar terlihat keren tapi karena adanya pandemik memaksa anak remaja untuk mengikuti aturan social distancing sehingga menyebabkan remaja menjadi tidak leluasa untuk melakukan kegiatan bersama teman-temannya. Menurut Hastuti \& Baiti (2019), masa remaja merupakan masa terjadinya perubahan baik secara fisik maupun emosional. Hal ini yang menyebabkan remaja mudah bergejolak dengan hal-hal atau perubahan yang terjadi disekitarnya. Dampaknya pergolakan emosi akan menyebabkan minimnya kemampuan remaja untuk mengontrol emosi sehingga berisiko mengalami stres. Remaja juga memiliki antusias yang tinggi, mereka memilih untuk melakukan aktivitas mereka diluar rumah bersama teman-teman, berkumpul dengan group, menunjukan eksistensi dan perasaan ingin diakui oleh teman sebaya.Stres merupakan pengalaman subyektif yang didasarkan pada persepsi seseorang terhadap situasi yang dihadapinya. Perubahan sosial yang terjadi saat ini memiliki pengaruh penting terhadap kejadian stres pada remaja. Ada beberapa penyebab stres pada remaja di masa pandemi, salah satunya adalah sosial distancing. Beberapa remaja merasa sangat bosan dalam melakukan segala aktivitas dari rumah, keinginan untuk berkumpul bersama teman-teman tidak dapat dilakukan dengan leluasa. Atziza (2015) juga mengatakan anak-anak/remaja memerlukan waktu untuk beradaptasi dengan perubahan baru yang juga berpengaruh pada kesehatan mental. Perubahan yang dapat dirasakan remaja saat ini ialah perubahan sosial karena adanya social distancing. 
Hasil dari penelitian ini diketahui bahwa responden yang melakukan sosial distancing dengan baik mengalami stres ringan sebanyak 43 (56.6\%). Lumban Gaol (2016) menjelaskan bahwa siswa dengan tingkat stres yang ringan terkadang lebih mudah mengalami reaksi berlebihan terhadap situasi yang dianggap sensitif, mudah tersinggung, cemas, ketidaksabaran dan gejala lainnya, dan terkadang merasa tidak nyaman ketika menghadapi penundaan dengan apa yang telah mereka lakukan. Sebuah subsampel pada penelitian Marroquín et al (2020) dari 118 peserta yang telah menyelesaikan tindakan gejala awal wabah menunjukkan peningkatan depresi dan GAD antara Februari dan Maret, dan perilaku menjaga jarak dikaitkan dengan peningkatan ini.

Dalam penelitian ini juga menemukan responden yang mengalami stres sedang sebanyak 11 (14.4\%), peneliti berasumsi responden yang mengalami stres sedang karena memiliki kemampuan dalam mengelola stres. Rahmawati et al (2019) menjelaskan bahwa tekanan sedang adalah tingkat stres yang berlangsung dalam jangka waktu yang lebih lama, dari beberapa jam hingga berhari-hari. Respon secara biologis terhadap tingkat stres ini biasanya terjadi pada lambung dan usus, seperti maag, buang air besar tidak teratur, ketegangan otot, gangguan pola tidur, perubahan siklus haid, dan penurunan konsentrasi serta daya ingat menurun. Tanda dan gejala lain juga dijelaskan oleh Rousset \& Halioua (2018) seperti merasa ingin badan akan jatuh dan pingsan dan sering merasa tidak mampu dalam melaksanakan kegiatan rutin seharihari.

Dalam penelitian ini juga peneliti mendapatkan hasil $1(1.3 \%)$ responden yang melakukan social distancing dengan baik mengalami tingkat stres yang berat, menurut asumsi peneliti, hal ini berhubungan dengan mekanisme koping individu yang tidak efektif dan responden selalu merasa tertekan dengan keadaan atau perubahan sosial yang terjadi. Ada dua faktor yang menjadi penyebab terjadinya stres berat yaitu faktor internal yang berasal dari dalam diri sendiri, seperti kondisi fisik, motivasi serta tipe kepribadian dan faktor eksternal seperti lingkungan, keluarga atau faktor akademis. Jika siswa biasanya berada di luar ruangan, maka jarak sosial dan kewajiban untuk tinggal di rumah bisa menjadi masalah besar. Siswa akan merasa terkurung di dalam rumah dan tidak dapat berbuat banyak kecuali berbaring atau membaca buku. Ini salah satu pemicu bagi seseorang yang mengalami gejala stress (Gimon, 2020). Keadaan stres berat menurut Rahmawati et al (2019) stres sangat berat merupakan penyakit kronis yang dapat terjadi dalam beberapa bulan atau dalam waktu yang tidak pasti. Umumnya orang yang stres sering kali menyerah dan tidak memiliki motivasi untuk hidup. Secara umum diyakini bahwa, orang-orang pada tingkat stres ini akan mengalami depresi berat dimasa depan.

Hasil lain dalam penelitian ini juga terdapat sel yang mendeskripsikan social distancing yang dilakukan dengan baik tetapi memiliki 5 (6,6\%) responden yang tidak mengalami stres. Peneliti berasumsi bahwa ini berhubungan juga dengan mekanisme atau koping dari responden itu sendiri, strategi koping merupakan cara yang digunakan oleh responden dalam mengelolah stresnya, karena strategi koping yang digunakan dengan tepat maka bisa menurun, bisa juga dari bagaimana responden menyikapi dan menghadapi perubahan interaksi yang terjadi selama social distancing. Aufar \& Raharjo (2020) yang mengatakan koping stres dimasa pandemi sangat penting, karena jika seseorang mampu menjaga kopingnya dengan baik, maka stres pun bisa berkurang, dalam hal ini yang bisa dilakukan salah satunya adalah relaksasi. Aktivitas relaksasi pada era teknologi tidak hanya dapat dilakukan melalui metode secara langsung tetapi juga telah hadir dalam berbagai platform digital ditengah masyarakat, sedangkan untuk responden yang melakukan sosial distancing kurang baik sebanyak $16(21,1 \%)$, responden ini berada dalam kategori tidak stres.

Penelitian ini juga selaras dengan penelitian yang dilakukan oleh Nasrudin et al (2020) dengan menggunakan desain cross sectional. Populasi diambil sebanyak 340 kepala keluarga dengan jumlah 809 orang. Sampel dalam penelitian ini sebanyak 92 responden remaja, tehnik pengambilan sampling yang digunakan adalah accidental sampling. Data diperoleh melalui kuisioner dengan hasil nilai $\mathrm{p}=0,000<$ $\alpha=0.05$, ini menunjukan bahwa ada hubungan antara jarak sosial terhadap stres pada remaja. penelitian lain yang dilakukan oleh Odriozola-González et al (2020) menunjukkan adanya hubungan antara jarak social dengan dampak psikologi, datanya diperoleh melalui pembagian kuisioner secara online dan menemukan hasil yang sama, dimana nilai $\mathrm{p}<\alpha$ dari total responden yang berjumlah 2530 .

\section{KESIMPULAN}

Persepsi tentang social distancing pada anak usia remaja berada dalam kategori baik dan tingkat stres siswa di SMP Frater Mamasa berada dalam kategori tingkat ringan. Hasil analisis menunjukkan terdapat hubungan antara social distancing dengan tingkat stres anak usia remaja di SMP Frater Mamasa. 


\section{REFERENSI}

Al Omari, O., Al Sabei, S., Al Rawajfah, O., Abu Sharour, L., Aljohani, K., Alomari, K., Shkman, L., Al Dameery, K., Saifan, A., Al Zubidi, B., Anwar, S., \& Alhalaiqa, F. (2020). Prevalence and Predictors of Depression, Anxiety, and Stress among Youth at the Time of COVID-19: An Online Cross-Sectional Multicountry Study. Depression Research and Treatment, 2020(March), 1-9. https://doi.org/10.1155/2020/8887727. Diakses pada 29 oktober 2020 pukul 23.11.

Atziza, R. (2015). Faktor-Faktor yang Mempengaruhi Kejadian Stres dalam Pendidikan Kedokteran Factors Influence Stress Incidence in Medical School. J Agromed Unila, 2(3), 1-4. https://juke.kedokteran.unila.ac.id/index.php/agro/article/view/1367. Diakses pada 12 september 2020 pukul 11.21.

Aufar, A. F., \& Raharjo, S. T. (2020). Kegiatan Relaksasi Sebagai Coping Stress Di Masa Pandemi Covid-19. Jurnal Kolaborasi Resolusi Konflik, 2(2), 157. https://doi.org/10.24198/jkrk.v2i2.29126. Diakses pada 16 september 2020 pukul 23.11.

Badan Pusat Statistik. (2020). Hasil Survei Sosial Demografi Dampak Covid-19 Provinsi Sulawesi Selatan 2020.122. diakses

https://sulsel.bps.go.id/publication/download.html?nrbvfeve=njkzymjmytviyzlizwq5zmrlowqxztjm\&xzmn= ahr0chm6ly9zdwxzzwwuynbzlmdvlmlk13b1ymxpy2f0aw9ulziwmjavmdcvmdkvnjkzymjmytviyzlizwq5zmr lowqxztjml2hhc2lslxn1cnzlas1zb3npywwtzgvtb2dyywzplwrhbxbhay1jb3zpzc0xo. Diakses pada 30 oktober 29.14.

Blakemore, S. J. (2019). Adolescence and mental health. The Lancet, 393(10185), 2030-2031. https://doi.org/10.1016/S0140-6736(19)31013-X. Diakses pada 23 oktober 14.33.

Cullen, W., Gulati, G., \& Kelly, B. D. (2020). Mental health in the COVID-19 pandemic. QJM : Monthly Journal of the Association of Physicians, 113(5), 311-312. https://doi.org/10.1093/qjmed/hcaa110. Diakses pada 29 oktober 2020 pukul 19.43 .

Dahlan, M. Sopiyudin. 2014. Statistik Untuk Kedokteran Dan Kesehatan:Deskriptif, Bivariat, dan Multivariat, di Lengkapi Aplikasi Dengan Menggunakan SPSS edisi 6. jakarta : Epidemiologi Indonesia.

Ettman, C. K., Abdalla, S. M., Cohen, G. H., Sampson, L., Vivier, P. M., \& Galea, S. (2020). Prevalence of Depression Symptoms in US Adults Before and During the COVID-19 Pandemic. JAMA Network Open, 3(9), e2019686. https://doi.org/10.1001/jamanetworkopen.2020.19686. Diakses pada 30 oktober 2020 pukul 13.59 .

Gimon, N. et al. (2020). Gambaran Stres Dan Body Image Pada Mahasiswa Semester VI Fakultas Kesehatan Masyarakat Universitas SAM Ratulangi Selama Masa Pandemi Covid-19. Jurnal KESMAS, Vol. 9(No. 6), Hlm. 17-26. Diakses pada 18 november 2020 pukul 22.59.

Hastuti, R. Y., \& Baiti, E. N. (2019). Hubungan Kecerdasan Emosional Dengan Tingkat Stress Pada Remaja. Jurnal Ilmiah Kesehatan, 8(2), 82-91. https://doi.org/10.35952/jik.v8i2.152. Diakses pada 17 oktober 2020 pukul 22.18.

Kandeger, A., Guler, H. A., Egilmez, U., \& Guler, O. (2018). Major depressive disorder comorbid severe hydrocephalus caused by Arnold - Chiari malformation Does exposure to a seclusion and restraint event during clerkship influence medical student' $s$ attitudes toward psychiatry? Indian Journal of Psychiatry, 59(4), $2017-2018$. https://doi.org/10.4103/psychiatry.IndianJPsychiatry. Diakses pada 30 oktober 2020 pukul 21.45.

Lumban Gaol, N. T. (2016). Teori Stres: Stimulus, Respons, dan Transaksional. Buletin Psikologi, 24(1), 1. https://doi.org/10.22146/bpsi.11224. Diakses pada 7 september 2020 pukul 11.50.

Marroquín, B., Vine, V., \& Morgan, R. (2020). Mental health during the COVID-19 pandemic: Effects of stay-at-home policies, social distancing behavior, and social resources. Psychiatry Research, 293(May), 113419. https://doi.org/10.1016/j.psychres.2020.113419. Diakses pada 28 september 2020 pukul 20.20.

Mohammadi, D. (2020). Research brief. The Lancet. Infectious Diseases, 20(2), 177. https://doi.org/10.1016/S14733099(20)30015-3. Diakses pada 12 september pukul 17.21.

Nasrudin, Umi Azizah, D. P. (2020). Dampak Isolasi Sosial Selama Pandemi Covid 19 Terhadap Remaja: Aktifitas , Emosional, Stress-Adaptasi Dan Strategi Koping. 4(2)

Nasruddin, R., \& Haq, I. (2020). Pembatasan Sosial Berskala Besar (PSBB) dan Masyarakat Berpenghasilan Rendah. SALAM: Jurnal Sosial Dan Budaya Syar-I, 7(7). https://doi.org/10.15408/sjsbs.v7i7.15569. Diakses pada 12 september 2020 pukul 15.41

Odriozola-González, P., Planchuelo-Gómez, Á., Irurtia, M. J., \& de Luis-García, R. (2020). Psychological effects of the COVID-19 outbreak and lockdown among students and workers of a Spanish university. Psychiatry Research, 290(May), 113108. https://doi.org/10.1016/j.psychres.2020.113108. Diakses pada 29 oktober 2020 pukul 16.10.

Piyeke, P., Bidjuni, H., \& Wowiling, F. (2014). Hubungan Tingkat Stres Dengan Durasi Waktu Bermain Game Online Pada Remaja Di Manado. Jurnal Keperawatan UNSRAT, 2(2), 105771.

Rahmawati, M. N., Rohaedi, S., \& Sumartini, S. (2019). Tingkat Stres Dan Indikator Stres Pada Remaja Yang Melakukan Pernikahan Dini. jurnal pendidikan keperawatan indonesia. https://doi.org/10.17509/jpki.v5i1.11180. Diakses pada 10 september 2020 pukul 20.11.

Rousset, L., \& Halioua, B. (2018). Stress and psoriasis. International Journal of Dermatology, 57(10), 1165-1172. https://doi.org/10.1111/ijd.14032. Diakses pada 7 september 2020 pukul 16.20. 